\section{Apparent Recovery and Efficiency of Nitrogen Fertilization in Tomato Grown on Sandy Soils}

\author{
Laura Jalpa ${ }^{1}$, Rao S. Mylavarapu ${ }^{1}$, George J. Hochmuth ${ }^{1}$, \\ Alan L. Wright ${ }^{1}$, and Edzard van Santen ${ }^{2}$
}

\begin{abstract}
ADDITIONAL INDEX WORDS. fertilization management practices, nutrient management, nutrient use efficiency, Solanum lycopersicum, vegetable production

SUMMARY. Use efficiency of applied nitrogen $(\mathrm{N})$ is estimated typically to be $<\mathbf{5 0 \%}$ in most crops. In sandy soils and warmer climates particularly, leaching and volatilization may be primary pathways for environmental loss of applied N. To determine the effect of $\mathrm{N}$ fertilization rate on the $\mathrm{N}$ use efficiency (NUE) and apparent recovery of $\mathrm{N}$ fertilizer (APR), a replicated field study with 'BHN 602' tomato (Solanum lycopersicum) grown in sandy soils under a fertigated plastic-mulched bed system was conducted using ammonium nitrate as the $\mathrm{N}$ source at four different rates $(0$, 150,200 , and $250 \mathrm{lb} /$ acre). Spring tomato was followed by fall tomato in the same field, a typical cropping sequence in north Florida. Fertigation of $\mathrm{N}$ fertilizer was applied weekly in 13 equal doses for both seasons. The highest NUE was $12.05 \%$ (spring) and $32.38 \%$ (fall), and the highest APR was $6.11 \%$ (spring) for the lowest rate of $\mathrm{N}$ applied ( $150 \mathrm{lb} / \mathrm{acre})$. In the fall, APR was unaffected by fertilizer $\mathrm{N}$ rates and ranged from $12.88 \%$ to $19.39 \%$. Nitrogen accumulation in tomato plants were similar among the three $\mathrm{N}$ fertilizer rates applied $(150,200$, and $250 \mathrm{lb} /$ acre $)$, though compared with no $\mathrm{N}$ fertilizer application, significant increases occurred. Whole plant $\mathrm{N}$ accumulation, NUE, and APR declined or remained similar when $\mathbf{N}$ rates increased above $150 \mathrm{lb} / \mathrm{acre}$. Additionally, a regression analysis and derivative of the quadratic fresh yield data showed that yields were maximized at 162 and 233 $\mathrm{lb} /$ acre $\mathrm{N}$ in the spring and fall seasons, respectively.
\end{abstract}

$\mathrm{F}$ lorida ranks first in the production of tomato in the United States [U.S. Department of Agriculture (USDA), 2011] and uses $\approx 30,000$ acres for production (USDA, 2018). Tomato production systems involve intensive management of nutrients and water on typically sandy textured soils. Optimizing applications of nutrient and water and their use efficiencies is, therefore, important for minimizing potential losses of nutrients to the environment, particularly nitrogen $(\mathrm{N})$, in sandy soils. Synthetic N fertilizer is a relatively low-cost input resulting in potential excessive applications. This

Received for publication 11 Sept. 2019. Accepted for publication 21 Jan. 2020.

Published online 20 February 2020.

${ }^{1}$ Soil and Water Sciences Department, 2181 McCarty Hall A, P.O. Box 110290, University of Florida, Gainesville, FL 32611-0290

${ }^{2}$ Agronomy Department and Statistical Consulting Unit, Institute of Food and Agricultural Sciences, P.O. Box 110500, University of Florida, Gainesville, FL 3261 1-0500

R.S.M. is the corresponding author. E-mail: raom@ ufl.edu.

This is an open access article distributed under the CC BY-NC-ND license (https://creativecommons.org/ licenses/by-nc-nd/4.0/).

https://doi.org/10.21273/HORTTECH04480-19 ultimately leads to leaching of $\mathrm{N}$ into groundwater through nitratenitrogen $\left(\mathrm{NO}_{3}-\mathrm{N}\right)$ pollution (Paltineanu et al., 1980) and degrades surface water bodies through eutrophication (Carpenter et al., 1998). In most agricultural soils, $\mathrm{NO}_{3}-\mathrm{N}$ is the dominant $\mathrm{N}$ form available for crop accumulation (Mengel and Kirkby, 2001), where agricultural sandy soils can intensify $\mathrm{NO}_{3}-\mathrm{N}$ leaching.

Nitrogen is a common limiting factor for tomato production in the southeastern United States (Everett, 1976; Locascio et al., 1997; Rhoads et al., 1996), resulting in significant $\mathrm{N}$ use. In Florida, the recommended rate of $\mathrm{N}$ fertilization for tomato production is $200 \mathrm{lb} /$ acre (Mylavarapu et al., 2017a), although commercial growers may apply more than double this amount (357-500 lb/acre) (Everett, 1976; Rhoads et al., 1996). With increases in the use of $\mathrm{N}$ fertilizer occurring, it is critical to produce information on fertilizer accumulation by the crop to improve production practices that can increase efficiency and decrease $\mathrm{N}$ fertilizer loss.

Nitrogen use efficiency (NUE) of agricultural systems is estimated at $50 \%$ (Smil, 1999), where unused $\mathrm{N}$ fertilizer may remain in the soil or be subject to denitrification, volatilization, and leaching to groundwater (Carpenter et al., 1998). Nitrogen use efficiency is defined as the $\mathrm{N}$ accumulation by plants divided by the amount of $\mathrm{N}$ fertilizer applied. Increasing NUE in agricultural production systems is of critical importance because the consumption and demand for $\mathrm{N}$ fertilizer will continue to grow as populations increase (Xu et al., 2012). In 2008, about 162 million tonnes of $\mathrm{N}$, phosphorous $(\mathrm{P})$, and potassium (K) fertilizer was used and has increased to 200 million tonnes of fertilizer in 2018 [Food and Agriculture Organization of the United Nations (FAO), 2015]. Of this 200 million tonnes, 119 million tonnes came from $\mathrm{N}$ alone (FAO, 2015). Currently, researchers and government agencies are attempting to look at optimizing NUE in agricultural production while minimizing negative impacts to the environment. For example, the Florida Department of Agriculture and Consumer Services (FDACS) implemented best management practices (BMPs) to

\begin{tabular}{llll}
\hline $\begin{array}{l}\text { Units } \\
\text { To convert U.S. to SI, } \\
\text { multiply by }\end{array}$ & U.S. unit & SI unit & $\begin{array}{l}\text { To convert SI to U.S., } \\
\text { multiply by }\end{array}$ \\
\hline 0.4047 & acre $(\mathrm{s})$ & $\mathrm{ha}$ & 2.4711 \\
29.5735 & $\mathrm{fl} \mathrm{oz}$ & $\mathrm{mL}$ & 0.0338 \\
0.3048 & $\mathrm{ft}$ & $\mathrm{m}$ & 3.2808 \\
3.7854 & $\mathrm{gal}$ & $\mathrm{L}$ & 0.2642 \\
2.54 & inch $(\mathrm{es})$ & $\mathrm{cm}$ & 0.3937 \\
25.4 & inch $(\mathrm{es})$ & $\mathrm{mm}$ & 0.0394 \\
1.1209 & $\mathrm{lb} / \mathrm{acre}$ & $\mathrm{kg} \cdot \mathrm{ha}^{-1}$ & 0.8922 \\
0.0254 & $\mathrm{mil}(\mathrm{s})$ & $\mathrm{mm}$ & 39.3701 \\
1 & $\mathrm{mmho} / \mathrm{cm}$ & $\mathrm{mS} \cdot \mathrm{cm}^{-1}$ & 1 \\
28.3495 & $\mathrm{oz}$ & $\mathrm{g}$ & 0.0353 \\
1 & $\mathrm{ppm}$ & $\mathrm{mg} \cdot \mathrm{kg}^{-1}$ & 1 \\
6.8948 & $\mathrm{psi}$ & $\mathrm{kPa}$ & 0.1450 \\
0.9072 & ton $(\mathrm{s})$ & tonne $(\mathrm{s})$ & 1.1023 \\
$\left({ }^{\circ} \mathrm{F}-32\right) \div 1.8$ & ${ }^{\circ} \mathrm{F}$ & ${ }^{\circ} \mathrm{C}$ & $\left({ }^{\circ} \mathrm{C} \times 1.8\right)+32$
\end{tabular}


reduce nutrient loading from agricultural production into bodies of water (FDACS, 2015). Efforts have included the improvement and implementation of soil test recommendations and other cultural practices to improve NUE of agricultural systems and reduce leaching (Way, 2007). For tomato production on sandy soils in Florida, BMPs include drip irrigation, splitting $\mathrm{N}$ fertilizer applications (13 weekly applications), and mulched beds, all of which help improve the NUE.

In addition to improving fertilizer $\mathrm{N}$ efficiency in tomato production systems, the agronomic apparent recovery of $\mathrm{N}$ fertilizer (APR) will be studied. The agronomic calculation of APR is defined as the difference in $\mathrm{N}$ accumulation (pounds per acre) between plots receiving fertilizer and unfertilized plots, and it is in proportion to the amount of $\mathrm{N}$ fertilizer applied. The APR index evaluates the ability of the crop to absorb soil N, where decreases in APR occur when $\mathrm{N}$ supply exceeds crop $\mathrm{N}$ demand (Greenwood and Hunt, 1986). A decline in APR, therefore, typically occurs when $\mathrm{N}$ fertilizer rates are increased. An APR value of zero would indicate that $\mathrm{N}$ accumulation of the unfertilized crops did not differ from those that were fertilized with $\mathrm{N}$ fertilizer. In other words, the plant likely took up native soil $\mathrm{N}$ primarily. On the other hand, an APR value of $100 \%$ indicates that $\mathrm{N}$ accumulation of the crop was higher than what was applied as $\mathrm{N}$ fertilizer (Craswell and Godwin, 1984; Mengel et al., 2006). Therefore, determining APR in vegetable production systems is important to ascertain the efficiency of applied $\mathrm{N}$ fertilizer to a system that may or may not provide sufficient native soil $\mathrm{N}$ to the crop.

Information on NUE and APR could aid in providing additional information on determining the efficiency of current management practices related to rate and timing of $\mathrm{N}$ fertilizer applications (Zemenchik and Albrecht, 2002). Limited information is available where NUE and APR are compared and evaluated together (Zemenchik and Albrecht, 2002 ), especially in the case of evaluating the efficiency of $\mathrm{N}$ fertilizer application on vegetable production systems. Therefore, a study was conducted on determining the efficiency of applied $\mathrm{N}$ fertilizer on tomato produced on sandy soils, using NUE and APR as indices of evaluating efficiency. Thus, our objectives were to determine the effect of $\mathrm{N}$ fertilization rate on the responses of tomato, including l) $\mathrm{N}$ accumulation in plant tissues, 2) crop $\mathrm{N}$ requirement, and 3 ) apparent recovery and efficiency of $\mathrm{N}$.

\section{Materials and methods}

FieLD SITE AND EXPERIMENTAL DESIGN. The field experiment was conducted at the University of Florida (UF), Plant Science Research and Education Unit in Citra, FL (lat. $29^{\circ} 24^{\prime} 8.78^{\prime \prime} \mathrm{N}$, long. 82 $10^{\circ} 31.56^{\prime \prime}$ W) for both Spring and Fall 2017. The area is characterized as having an udic moisture regime, with high humidity and precipitation during most of the year. Mean annual precipitation is $\approx 1200-1400 \mathrm{~mm}$, and mean annual temperature ranges from 20 to $24^{\circ} \mathrm{C}$ with a frost-free period of 276 to 306 d (USDA, 2017). The soil at the experimental site is classified as a Gainesville loamy sand, hyperthermic, coated typic quartzipsamments, with a parent material of sandy marine deposits (USDA, 2017). Soil is acidic and well drained, with a high to very high hydraulic conductivity $(0.15-0.5$ $\left.\mathrm{m} \cdot \mathrm{h}^{-1}\right)$. The depth to water table is more than $2 \mathrm{~m}$ deep with a low available water storage capacity of $0.1 \mathrm{~m}$ (USDA, 2017).

The study area was rototilled and $\mathrm{l}$-ft-high, raised beds were made with $5 \mathrm{ft}$ between beds. To prevent nematode infestation, plots were fumigated with $170 \mathrm{lb} /$ acre chloropicrin +111 $\mathrm{lb} /$ acre 1,3-dichloropropene (PicChlor 60; TriEst Ag Group, Greenville, NC). Along with fumigating, a single line of drip irrigation tape (12-inch emitter spacing, $0.50 \mathrm{gal} /$ min per $100 \mathrm{ft}$ at $15 \mathrm{psi}$; Jain Irrigation, Haines City, FL) was laid and beds were covered with a 1.25-mil-thick totally impermeable film plastic mulch (Raven Industries, Sioux Falls, SD). Holes were punched into the plastic about $1.5 \mathrm{ft}$ apart for transplanting. Air temperature and precipitation were measured by the Florida Automated Weather Network at UF for spring and fall seasons (Fig. 1).

There were four $\mathrm{N}$ rates with $0 \mathrm{~N}$ control, 150, 200, and $250 \mathrm{lb} / \mathrm{acre}$, where the $\mathrm{N}$ source was ammonium nitrate fertilizer. Treatments were arranged in a randomized complete block design with four replications. Four 160-ft-long beds were used, where 16 experimental units were laid out. Each plot was $3 \mathrm{ft}$ wide and $40 \mathrm{ft}$ long with 3 - $\mathrm{ft}$ buffers in between each plot. Treatment rates for $\mathrm{N}$ applications were based on the UF, Institute of Food and Agriculture Sciences (IFAS) recommendation for tomato, which is $200 \mathrm{lb} /$ acre (Mylavarapu et al., 2017a). Therefore, $-25 \%$ (150 $\mathrm{lb} / \mathrm{acre})$ and $+25 \%(250 \mathrm{lb} /$ acre $)$ of the recommended $\mathrm{N}$ rate and a control were applied as the other treatments. Soil $\mathrm{pH}$, electrical conductivity (EC), organic matter (OM), and Mehlich-3 (M-3) extracted K and $P$ of soil samples from the top 6 inches were collected before planting. Information on the texture was collected, and these data are presented in Table 1 . Both $\mathrm{P}$ and $\mathrm{K}$ levels in soil at preplant were high; thus, no $\mathrm{P}$ or $\mathrm{K}$ fertilizers were applied.

Three weeks after fumigating, 'BHN 602' tomato seedlings were

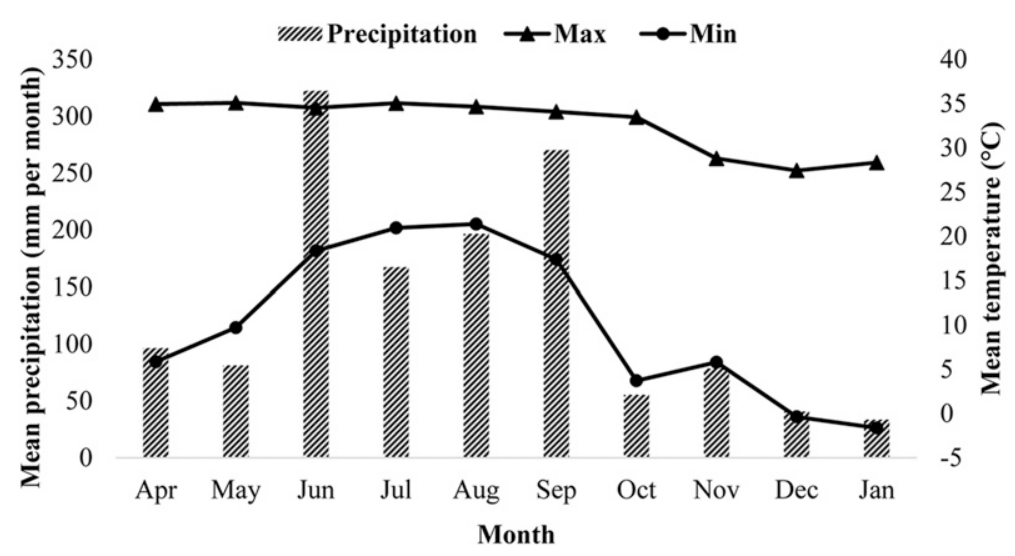

Fig. 1. Mean monthly total precipitation and temperatures at the study site in northern Florida. Planting dates for tomato were $24 \mathrm{Apr}$. and $2 \mathrm{Oct}$. in Spring and Fall 2017, respectively; $1 \mathrm{~mm}=0.0394$ inch, $\left({ }^{\circ} \mathrm{C} \times 1.8\right)+32={ }^{\circ} \mathrm{F}$. 
transplanted on 24 Apr. 2017. Within each of the four beds, 15 plants were planted per treatment, where 5 plants were randomly collected for analysis in both seasons. Seven days after transplanting (DAT), ammonium nitrate fertilization was applied weekly in 13 equal doses both seasons. Irrigation was started immediately after transplanting and was run twice per day at $30-\mathrm{min}$ intervals, with a flow rate of $0.5 \mathrm{gal} / \mathrm{min}$ per $100 \mathrm{ft}$ of tape (18 psi).

Tomato were harvested through multiple pickings (at 70, 73, 78, 80, 83 , and 90 DAT), when maturegreen. Tomato fruits were weighed to compute yield. A composite subsample of the fruit from each experimental unit was selected after each picking and then cut and dried for a week to obtain dry matter yield. Aboveground biomass was collected at 94 and 95 DAT, and soil samples were collected at 92 DAT for all plots at a 6-inch depth using a hand-operated core sampler. The soil samples were then measured for $\mathrm{pH}, \mathrm{EC}, \mathrm{OM}$, and M-3-extracted $P$ and $K$ (Table 2 ).

On 16 Aug. 2017, the old plastic was taken off the beds and beds were reshaped, fumigated, and covered in white plastic mulch. Six weeks after fumigation, transplanting occurred on 2 Oct. 2017.

Tomato plants are susceptible to chilling injury (CI) at temperatures below $12{ }^{\circ} \mathrm{C}$ (Heuvelink, 2005). Fall- planted tomatoes experienced $\approx 45$ d of suboptimal weather, where minimum temperatures ranged from -1 to $11{ }^{\circ} \mathrm{C}$ (Fig. 1). Long sheets of plastic were cut into 16 pieces to cover the plots and protect them from CI at 68 and 69 DAT. Fruit growth was prolonged, possibly due to cold temperatures. Therefore, a harvest was conducted at $81 \mathrm{DAT}$ to collect the mature-green tomatoes at the time; and once matured, the rest of the tomatoes were harvested at 100 and 101 DAT. Soil samples were taken at 102 DAT and aboveground biomass were collected at 106 and 107 DAT, respectively. Soil samples collected in the top 6 inches were analyzed for $\mathrm{pH}, \mathrm{EC}, \mathrm{OM}$, and $\mathrm{M}-3$ extracted $\mathrm{P}$ and $\mathrm{K}$ (Table 2 ).

SoIL AND TISSUE ANALYSIS. All plant and soil samples were analyzed at the UF/IFAS Analytical Services Laboratories in Gainesville as per standard procedures (Mylavarapu et al., 2017b).

All whole plant samples were dried for a week at $65{ }^{\circ} \mathrm{C}$ and were then subsequently separated into fruit and shoot, where the shoot consists of the petiole, leaf blade, and stem of the plant. Each plant component was weighed to obtain dry weights. The dry weights were used to calculate dry matter yield of the whole plant (fruit and shoot) (Fig. 2). Each plant component was ground in a Wiley mill (Laboratory Model 3 Mill; Thomas

Table 1. Soil physical and chemical properties for the surface [0-6 inches $(\mathbf{1 5 . 2}$ $\mathrm{cm})]$ profile at the experimental site measured at the preplant stage.

\begin{tabular}{lcl}
\hline Soil parameter $^{\mathrm{z}}$ & Preplant & \multicolumn{1}{c}{ Method of analysis } \\
\hline Sand $(\%)$ & 82.2 & Laser diffraction particle size analyzer \\
Silt $(\%)$ & 14.2 & \\
Clay $(\%)$ & 3.6 & \\
Organic matter $(\%)$ & 1.12 & Combustion \\
Extractable phosphorous $\left(\mathrm{mg} \cdot \mathrm{kg}^{-1}\right)$ & 152 & Mehlich-3 Soil Extraction Method \\
Extractable potassium $\left(\mathrm{mg} \cdot \mathrm{kg}^{-1}\right)$ & 92 & Mehlich-3 Soil Extraction Method \\
pH $(2: 1$ in water $)$ & 6.3 & EPA Method 120.1 \\
\hline
\end{tabular}

${ }^{\mathrm{z}} \mathrm{l} \mathrm{mg} \cdot \mathrm{kg}^{-1}=1 \mathrm{ppm}$.
Wiley, Swedesboro, NJ). To obtain total organic $\mathrm{N}$, plant parts were analyzed for total Kjeldahl (TKN) [TKN-U.S. Environmental Protection Agency (EPA) Method 351.2] on an air-segmented continuous autoflow analyzer (Flow Solution IV; Astoria-Pacific, Clackamas, OR). The plant accumulation of $\mathrm{N}$ was calculated by multiplying the dry matter yield by the TKN concentration in the plant (Table 3 ).

Soil samples were dried at $105^{\circ} \mathrm{C}$ for $24 \mathrm{~h}$ and were ground and sieved through a 2 -mm sieve for each 6 -inch increment sample. Soil organic matter was determined through the combustion method. The M-3 extractable $\mathrm{P}$ and $\mathrm{K}$ concentrations were determined using $2.5 \mathrm{~g}$ of soil and $10 \mathrm{~mL}$ of M-3 extractant. The concentrations of $\mathrm{P}$ and $\mathrm{K}$ were determined using inductively coupled plasmaoptical emission spectroscopy [ICP-OES (Optima 7000 DV ICPOES; PerkinElmer, Waltham, MA)]. EC (EPA Method 150.1) and $\mathrm{pH}$ (EPA Method 120.1) were also determined.

APR AND NUE eVAluation. The agronomic calculation of APR is defined as the difference in $\mathrm{N}$ accumulation (pounds per acre) between plots receiving fertilizer and unfertilized plots, and in proportion to the amount of $\mathrm{N}$ fertilizer applied (Mengel et al., 2006). In the literature, APR may also be termed as the difference method (Syers et al., 2008) and apparent recovery efficiency (ARE) (Baligar et al., 2001). There are several definitions of NUE, where the use of $\mathrm{N}$ can be expressed as the ratio of an output (e.g., total plant $\mathrm{N}$ accumulation, biomass accumulation yield, fruit yield) and an input (e.g., additions of $\mathrm{N}$ fertilizer, native soil $\mathrm{N}$, total N) (Masclaux-Daubresse et al., 2010). Terms such as the agronomic efficiency (AE) with the balance method (Syers et al., 2008), partial

Table 2. Soil chemical properties for the surface $[0-6$ inches $(15.2 \mathrm{~cm})]$ profile at the experimental site measured at harvest in the spring and fall seasons.

\begin{tabular}{lccc}
\hline Soil parameter & Spring & Fall & Method of analysis \\
\hline Organic matter $(\%)$ & 1.43 & 1.38 & Combustion \\
Extractable phosphorous $\left(\mathrm{mg} \cdot \mathrm{kg}^{-1}\right)$ & 211 & 381 & Mehlich-3 Soil Extraction Method \\
Extractable potassium $\left(\mathrm{mg} \cdot \mathrm{kg}^{-1}\right)$ & 35 & 29 & Mehlich-3 Soil Extraction Method \\
$\mathrm{pH}(2: 1$ in water $)$ & 6.2 & 6.2 & EPA Method 120.1 \\
EC $\left(\mathrm{mS} \cdot \mathrm{cm}^{-1}\right)$ & 0.12 & 0.12 & EPA Method 150.1 \\
\hline
\end{tabular}

${ }^{\mathrm{z}} 1 \mathrm{mg} \cdot \mathrm{kg}^{-1}=1 \mathrm{ppm}, \mathrm{l} \mathrm{mS} \cdot \mathrm{cm}^{-1}=1 \mathrm{mmho} / \mathrm{cm}$. 
nutrient balance (Fixen et al., 2015), and nutrient/fertilizer use efficiency (Fixen et al., 2015) are other terms that may also be found to describe NUE in the literature. However, NUE in this study is defined as the $\mathrm{N}$ accumulation in plants divided by the total amount of $\mathrm{N}$ fertilizer applied. The APR and NUE were calculated in the following equations:

$$
A P R(\%)=\left(\frac{N_{f}-N_{u f}}{N_{a}}\right) \times 100,
$$

where $N_{f}$ and $N_{u f}$ were biomass (fruit + shoot) $\mathrm{N}$ accumulation in fertilized and unfertilized plots (pounds per acre), and $N_{a}$ is the amount of $\mathrm{N}$ fertilizer applied (pounds per acre).

$$
\operatorname{NUE}(\%)=\frac{N_{f}}{N_{a}} \times 100,
$$

where $N_{f}$ is $\mathrm{N}$ accumulation in the fertilized plot (pounds per acre), and $N_{a}$ is the amount of $\mathrm{N}$ fertilizer applied (pounds per acre).

Statistical analysis. Data were analyzed using statistical software (JMP 14.1; SAS Institute, Cary, $\mathrm{NC}$ ). A one-way analysis of variance, with $\mathrm{N}$ rate as one fixed factor, with the block as a random effect, was applied to evaluate treatment effect on mean dry matter yield, $\mathrm{N}$

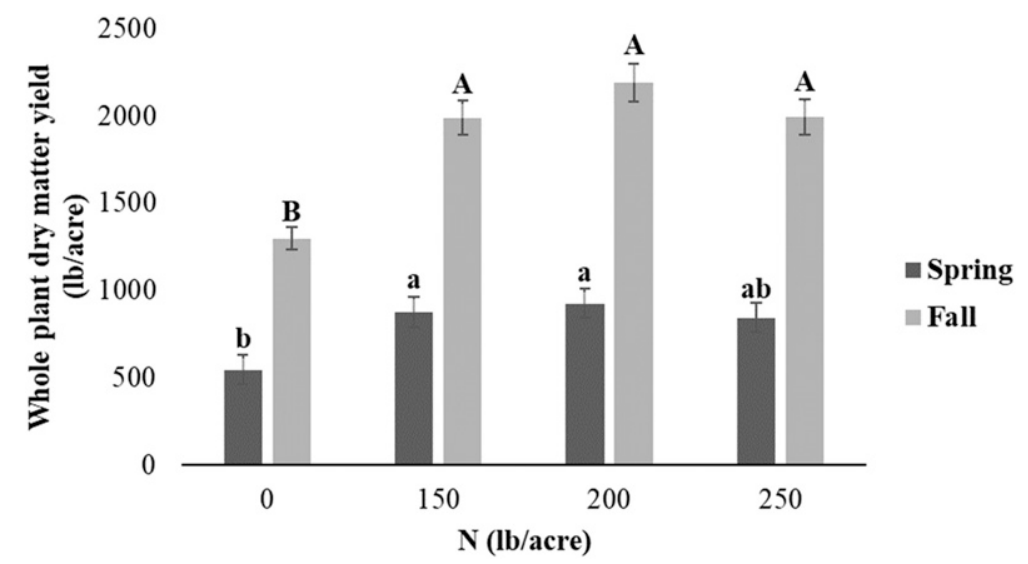

Fig. 2. Effect of nitrogen $(\mathrm{N})$ fertilizer rate on mean whole plant dry matter yield in Spring and Fall 2017 seasons in northern Florida. Lowercase letters indicate differences $(P<0.05)$ among treatments in spring and uppercase letters indicate differences $(P<0.05)$ among treatments in fall season; $1 \mathrm{lb} / \mathrm{acre}=1.1209 \mathrm{~kg} \cdot \mathrm{ha}^{-1}$. accumulation (pounds per acre), $\mathrm{APR}$, and NUE, in a randomized complete block design through TukeyKramer honestly significant difference post-hoc test. The confidence level was tested at $\alpha=0.05 P$. Analysis for treatment effects of $\mathrm{N}$ rate was done separately for each season (spring and fall) because of differences in weather conditions between the two seasons. A second-order polynomial regression analysis $(y=$ $\left.a x^{2}+b x+c\right)$ was conducted on fruit yield to determine the $\mathrm{N}$ rate at which yield is maximized in the spring and the fall seasons.

\section{Results and discussion}

SoIL FERTILITy INDices AT PREPLANT. At preplant stage, soil chemical properties of OM, M-3 extracted $\mathrm{P}$ and $\mathrm{K}$, and $\mathrm{pH}$ were $1.12 \%, 152$ and $92 \mathrm{mg} \cdot \mathrm{kg}^{-1}$, and 6.3 , respectively (Table 1 ). Therefore, addition of $\mathrm{P}, \mathrm{K}$, and lime were not needed. EC was not measured at preplant but was recorded at harvest in the spring and fall seasons.

Plant accumulation of $\mathbf{N}$ FerTilizer. Control plant parts had the lowest $\mathrm{N}$ accumulation of $\mathbf{3 . 3 5}$ $\mathrm{lb} /$ acre (fruit), $5.56 \mathrm{lb} /$ acre (shoot), and $8.9 \mathrm{l} \mathrm{lb} /$ acre (whole plant), when compared with fertilized plants in the spring (Table 3). In the whole plant, around $62 \%$ to $71 \%$ of $N$ accumulated in the shoot. Among the three $\mathrm{N}$ rates, similar $\mathrm{N}$ accumulations were

Table 3. Effect of nitrogen (N) fertilizer rate on $\mathrm{N}$ accumulation by tomato plant parts, $\mathrm{N}$ use efficiency (NUE), and apparent

\begin{tabular}{|c|c|c|c|c|c|c|c|}
\hline \multirow[b]{2}{*}{ Plant part } & \multirow[b]{2}{*}{$\mathrm{N}$ rate $(\mathrm{lb} / \mathrm{acre})^{\mathrm{z}}$} & \multicolumn{2}{|c|}{$\begin{array}{l}\text { Mean } \mathrm{N} \text { accumulation } \\
(\mathrm{lb} / \text { acre })^{\mathrm{z}}\end{array}$} & \multicolumn{2}{|c|}{ Mean NUE (\%) } & \multicolumn{2}{|c|}{ Mean APR (\%) } \\
\hline & & Spring & Fall & Spring & Fall & Spring & Fall \\
\hline \multicolumn{8}{|l|}{ Fruit } \\
\hline & 0 & $3.35 b^{y}$ & $0.79 \mathrm{~B}^{\mathrm{y}}$ & & & & \\
\hline & 150 & $6.50 \mathrm{a}$ & $2.15 \mathrm{~A}$ & & & & \\
\hline & 200 & $5.87 \mathrm{a}$ & $2.01 \mathrm{~A}$ & & & & \\
\hline & 250 & $4.76 \mathrm{a}$ & $2.26 \mathrm{~A}$ & & & & \\
\hline \multicolumn{8}{|l|}{ Shoot } \\
\hline & 0 & $5.56 \mathrm{~b}$ & $18.70 \mathrm{~B}$ & & & & \\
\hline & 150 & $11.58 \mathrm{a}$ & $46.42 \mathrm{~A}$ & & & & \\
\hline & 200 & $12.68 \mathrm{a}$ & $55.16 \mathrm{~A}$ & & & & \\
\hline & 250 & $11.62 \mathrm{a}$ & $49.43 \mathrm{~A}$ & & & & \\
\hline \multicolumn{8}{|l|}{ Whole plant } \\
\hline & 0 & $8.91 \mathrm{~b}$ & $19.49 \mathrm{~B}$ & - & - & - & - \\
\hline & 150 & $18.08 \mathrm{a}$ & $48.57 \mathrm{~A}$ & $12.05 \mathrm{a}$ & $32.38 \mathrm{~A}$ & $6.11 \mathrm{a}$ & $19.39 \mathrm{~A}$ \\
\hline & 200 & $18.55 \mathrm{a}$ & $57.17 \mathrm{~A}$ & $9.28 \mathrm{~b}$ & $28.59 \mathrm{AB}$ & $4.82 \mathrm{ab}$ & $18.84 \mathrm{~A}$ \\
\hline & 250 & $16.38 \mathrm{a}$ & $51.69 \mathrm{~A}$ & $6.55 \mathrm{c}$ & $20.68 \mathrm{~B}$ & $2.99 \mathrm{~b}$ & $12.88 \mathrm{~A}$ \\
\hline
\end{tabular}
recovery of N (APR) in Spring and Fall 2017 seasons in northern Florida.

${ }^{\mathrm{z}} 1 \mathrm{lb} /$ acre $=1.1209 \mathrm{~kg} \cdot \mathrm{ha}^{-1}$.

y Values followed by the same letter within a column indicate not statistically significantly different $(P<0.05)$ within the four $\mathrm{N}$ fertilizer rates according to Holm-Tukey adjust. Lowercase letters indicate differences $(P<0.05)$ among treatments in the spring and uppercase letters indicate differences $(P<0.05)$ among treatments in the fall season. 
found showing the application of $\mathrm{N}$ fertilizer had a positive effect on increasing $\mathrm{N}$ accumulation in the plant, but no significant increases were found when applications of $\mathrm{N}$ fertilizer were above $150 \mathrm{lb} /$ acre.

In the fall, similar $\mathrm{N}$ accumulations were observed among the three $\mathrm{N}$ rates applied, where the control resulted in the lowest $\mathrm{N}$ accumulation of $0.79 \mathrm{lb} /$ acre (fruit), $18.70 \mathrm{lb} /$ acre (shoot), and $19.49 \mathrm{lb} /$ acre (whole plant) (Table 3). About $96 \%$ to $97 \%$ of $\mathrm{N}$ accumulation in the whole plant came from the shoot, showing that the majority of $\mathrm{N}$ partitioning went to vegetative growth and less than $10 \%$ of $\mathrm{N}$ went to reproductive growth.

ApParent Recovery AND N USE EFFICIENCY. Nitrogen use efficiency was calculated at harvest and is defined as $\mathrm{N}$ accumulation in plants, divided by the total amount of $\mathrm{N}$ fertilizer applied. The highest NUE of $12.05 \%$ (spring) and $32.38 \%$ (fall) were recorded when the lowest rate of $150 \mathrm{lb} /$ acre was applied (Table 3). Nitrogen use efficiency significantly decreased with increasing rates of $\mathrm{N}$ fertilizer applied in both seasons, which is a typical result in many $\mathrm{N}$ fertilizer rate studies (Anderson et al., 1999; Hochmuth and Cordasco, 2000; Hochmuth and Hanlon, 2014; Zotarelli et al., 2009a, 2009b).

In spring, the highest APR was $6.11 \%$ for the lowest $\mathrm{N}$ rate applied (150 lb/acre) (Table 3). However, the APR obtained at the lowest fertilizer $\mathrm{N}$ rate of $150 \mathrm{lb} /$ acre was like the $\mathrm{N}$ rate of $200 \mathrm{lb} / \mathrm{acre}$. In the fall, among the three $\mathrm{N}$ rates $(150,200$, and $250 \mathrm{lb} /$ acre), APR was similar and ranged from $12.88 \%$ to $19.39 \%$ (Table 3). An APR value of zero indicates that $\mathrm{N}$ accumulation in the unfertilized plant did not differ from that in the fertilized plant (Craswell and Godwin, 1984; Mengel et al., 2006). In other words, there was enough $\mathrm{N}$ available in the soil for plant accumulation, and $\mathrm{N}$ fertilizer inputs were excessive and were not required to fulfill the crop $\mathrm{N}$ requirement. Therefore, the low APR values that resulted in spring and fall show that soil $\mathrm{N}$ was able to contribute to the crop $\mathrm{N}$ requirement; and although APR values were similar among the $\mathrm{N}$ rates, the $150 \mathrm{lb} / \mathrm{acre}$ $\mathrm{N}$ rate was sufficient to help meet the crop $\mathrm{N}$ requirement. Kadiyala et al. (2014) determined through a field study on rice (Oryza sativa) that the apparent $\mathrm{N}$ recovery decreased with increased rate of application $\mathrm{N}$.

The APR helped to show the difference between the contributions of native soil $\mathrm{N}$ that accumulated in unfertilized plants compared with the fertilized plants. Without taking native soil $\mathrm{N}$ accumulation by unfertilized plants into consideration, values obtained by NUE were of course much higher than APR. Although there was no difference in the benefits of applied $\mathrm{N}$ fertilizer rates on plant accumulation, NUE values were still useful in determining the most efficient $\mathrm{N}$ fertilizer rate. Such information could aid in improving management practices and $\mathrm{N}$ fertilizer rates that do significantly impact crop yield through increased efficiency.

This study compared the relative use efficiencies within each season. Increases in use efficiencies between seasons may have to do with higher yields and overall $\mathrm{N}$ accumulation experienced in the fall season. About $96 \%$ to $97 \%$ of $\mathrm{N}$ accumulation in the plant came from shoots in the fall. Shoot $\mathrm{N}$ accumulation was around $62 \%$ to $71 \%$ in the spring. Therefore, $\mathrm{N}^{*}$ accumulation increased roughly $40 \%$ to $43 \%$ from spring to fall. However, efficiencies were not analyzed for comparison between the seasons, because comparisons may not be reliable under the circumstance in which seasonal temperatures negatively impacted both the spring and the fall seasons.

EFFECT OF N FERTILIZER ON TOMATO FRUIT AND DRY MATTER YIELD. Planting dates for both spring and fall seasons were delayed beyond the typical times for tomato production in northern Florida. Thus, overall productivity (e.g., biomass production and yields) were not ideal because the plants were grown under conditions that included heat and cold stresses. Delayed planting in the spring exposed plants to higher temperatures during the early growth stages, thus affecting plant stand growth and limiting the ability of the crop to reach full potential productivity. A few degrees above the optimal temperature can reduce overall productivity of tomato and limit fruit set (Sato et al., 2000). Therefore, temperature strongly influences final fruit size, where temperatures above $26{ }^{\circ} \mathrm{C}$ tend to shorten the fruit growth period because of an increase in fruit development rate, reduced flower production, and reduction in pollen grain release and viability (Charles and Harris, 1972; Heuvelink, 2005; Sato et al., 2000). Also, Adams et al. (2001) found that $\approx 40 \%$ of the terminal meristems in tomato plants were died when plants were grown at $26{ }^{\circ} \mathrm{C}$. Therefore, trusses of the plant grew to be abnormal, where some trusses had reduced flower bud numbers or were aborted completely, thus leading to poor fruit set. In the same study, tomato plants grown at 22 and $18{ }^{\circ} \mathrm{C}$ produced higher fruit set and had a normal canopy structure (Adams et al., 2001). Maximum temperatures ranged from 32 to $34{ }^{\circ} \mathrm{C}$ in the spring (Fig. 1); and therefore conditions for optimal fruit growth were negatively impacted and resulted in lower yields due to poor fruit set.

In the spring, a regression analysis and derivative of the quadratic fresh yield data showed that yields were maximized at $162 \mathrm{lb} /$ acre of $\mathrm{N}$. The details are illustrated in Fig. 3 , where the dotted line indicates the current recommended $\mathrm{N}$ rate for tomato. Various $\mathrm{N}$ fertilizer rate studies conducted on sandy soils have concluded that no appreciable tomato yield increase occurred with $\mathrm{N}$ fertilizer rates above the recommended $\mathrm{N}$ rate of $200 \mathrm{lb} /$ acre (Anderson et al., 1999; Hochmuth and Cordasco, 2000; Hochmuth and Hanlon, 2014; Zotarelli et al., 2009a, 2009b); and if higher yields did occur, it was probably due to additional yields from later-season fruit production (Hochmuth and Hanlon, 2014). Our results showed that no appreciable increase in tomato yield was obtained with higher $\mathrm{N}$ rates, and $162 \mathrm{lb} /$ acre met the crop $\mathrm{N}$ requirement in the spring.

The fall season planting was similarly delayed because of hurricane Irma in September and this caused the tomato season to be extended (October) in the season marked with cooler temperatures. Suboptimal temperatures for tomato can be defined as CI, which occurs at temperatures below $12{ }^{\circ} \mathrm{C}$. Tomato plants are susceptible to CI and no substantial growth is expected when plants are exposed to this temperature for long periods of time (Heuvelink, 2005). Minimum temperatures ranged 


\begin{tabular}{|c|c|c|c|c|c|c|}
\hline \multirow[b]{2}{*}{ Season } & \multicolumn{2}{|c|}{ Intercept } & \multicolumn{2}{|c|}{ Linear } & \multicolumn{2}{|c|}{ Quadratic } \\
\hline & Estimate & SE & Estimate & SE & Estimate & $\mathrm{SE}$ \\
\hline Spring & 2878 & 1118 & 42.1 & 17.5 & -0.13 & 0.06 \\
\hline Fall & 4980 & 1490 & 41.9 & 25.7 & -0.09 & 0.09 \\
\hline
\end{tabular}

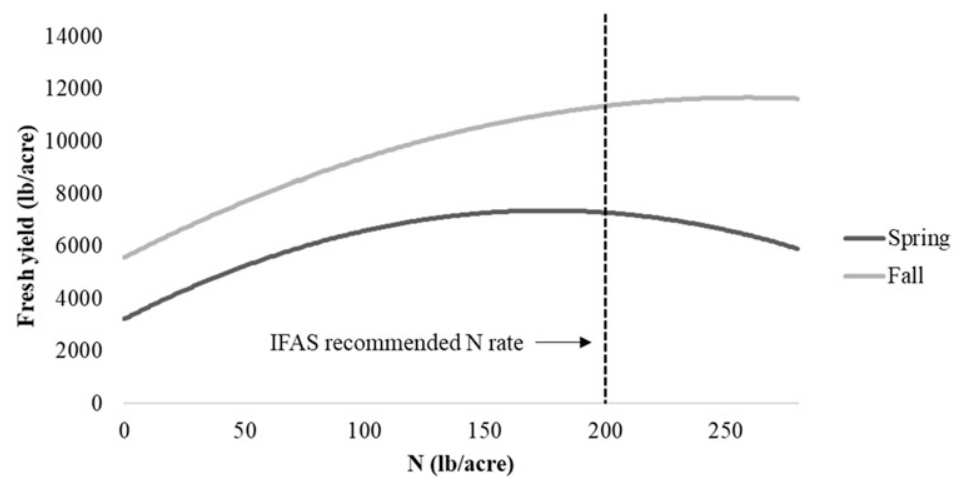

Fig. 3. Regressions of nitrogen $(\mathrm{N})$ fertilizer rate to fruit yield in Spring and Fall 2017 seasons in northern Florida. Dashed line indicates the University of Florida Institute of Food and Agricultural Sciences (UF/IFAS) recommended N rate for tomato, which is $200 \mathrm{lb} / \mathrm{acre} ; 1 \mathrm{lb} / \mathrm{acre}=1.1209 \mathrm{~kg} \cdot \mathrm{ha}^{-1}$.

from 6 to $11{ }^{\circ} \mathrm{C}$, where tomatoes experienced $45 \mathrm{~d}$ of suboptimal conditions in the fall (Fig. 1).

In the fall, the regression analysis showed that maximum yields occurred around $233 \mathrm{lb} /$ acre of $\mathrm{N}$. The current recommendation for optimum tomato production is $200 \mathrm{lb} /$ acre of $\mathrm{N}$, indicating that the fall season resulted in higher $\mathrm{N}$ uptake than what is typical. However, additional multiyear field research studies will be required before attempting to fine-tune/increase the current recommendations. Additionally, the regression analysis was conducted using few and uneven spacing between the rates. This likely made the response estimate somewhat unreliable, especially when the response estimate is reflecting conditions other than what is typical, due to late planting dates. Therefore, studies with evenly spaced multiple $\mathrm{N}$ rates will be needed to obtain a conclusive evidence on the $\mathrm{N}$ requirement for optimal tomato production.

In the spring, higher fruit $\mathrm{N}$ but lower fruit yield was found, whereas lower fruit $\mathrm{N}$ but higher fruit yield was found in the fall (Table 3 ). In other words, higher yield in the fall was accompanied by lower fruit $\mathrm{N}$ concentration. This could be because of the shortened spring season and the prolonged fall season experienced during the growing seasons. As mentioned, poor fruit set was experienced in the spring due to an increase in fruit development rate when tomato plants were grown at $26^{\circ} \mathrm{C}$ (Adams et al., 2001). Adams et al. (2001) found that tomato fruit growth was greatly reduced at $14{ }^{\circ} \mathrm{C}$ and trusses had many flowers, which increased the possibility of fruit set. At this temperature fruit were found to be smaller and harder. In other words, lower temperatures decreased the absolute growth rates and delayed the time at which the absolute growth rate maximizes. Therefore, in the fall, better fruit set was experienced, but fruit were found to be smaller.

The control plots had the lowest dry matter yield compared with the 150 and $200 \mathrm{lb} /$ acre $\mathrm{N}$ rates in spring (Fig. 2). Similar yields were found between the control and the highest $\mathrm{N}$ rate $(250 \mathrm{lb} / \mathrm{acre})$; though among the three $\mathrm{N}$ rates $(150,200$, and 250 $\mathrm{lb} / \mathrm{acre}$ ), yields were also similar. In fall, the control had the lowest dry matter yield, and similar yields were found among the three $\mathrm{N}$ rates (Fig. 2 ). This shows that a lower treatment of $150 \mathrm{lb} /$ acre of fertilizer applied did not limit biomass accumulation and that adding higher amounts of fertilizer did not provide a benefit in increasing biomass accumulation. Similar results were observed in other tomato studies, where higher $\mathrm{N}$ rate applications did not result in additional biomass accumulation (Zotarelli et al., 2009a, 2009b; Zuraiqi et al., 2002). As mentioned, overall productivity of tomato was impacted by temperature stress and therefore, dry matter yields were low for both seasons. The low dry matter yields obtained, therefore, indicate that low $\mathrm{N}$ use occurred in both seasons. This is supported by the low NUE obtained in the spring (13.64\%) and in the fall $(33.43 \%)$ seasons (Table 3 ). Any unused $\mathrm{N}$ in the spring and fall seasons can be assumed to have been lost due to leaching. Although leaching was not measured, applications of $\mathrm{N}$ on sandy soils will eventually be lost to leaching beyond the root zone. Zotarelli et al. (2007) conducted lysimeter experiments for vegetable production in Florida. The application method for this study used weekly fertigation of $\mathrm{N}$ over the tomato growth period. For tomato production, they found that the potential for $\mathrm{N}$ leaching increased by $59 \%$ for tomatoes under drip irrigated, plastic mulch production systems, when $\mathrm{N}$ fertilization is applied above the recommended $\mathrm{N}$ rate $(200 \mathrm{lb} /$ acre of $\mathrm{N}$ for tomatoes). Under the conditions that are typical of the southeastern United States, most of the soil N, regardless of $\mathrm{N}$ source (e.g., ammonium, nitrate, or urea forms), will rapidly be converted to $\mathrm{NO}_{3}-\mathrm{N}$, which is more susceptible to leaching on sandy soils (Jansson and Persson, 1982).

SOIL FERTILITY INDICES AT HARVEST. At harvest there was a small increase in the soil OM at the end of the crop season, when compared with preplant values (Table 1 ) in spring and in fall (Table 2). The soil OM values were estimated to be $1.43 \%$ in the spring and $1.38 \%$ in the fall, which we believe are appropriate for the crop, the soil, and the management system. The increase of OM content in the top 6 inches of soil profile could be due to plant biomass produced from root turnover that accumulated under the plastic mulch over the growing season. Organic matter content will take longer to mineralize as opposed to granular $\mathrm{N}$ fertilizer, indicating that increases in OM content perhaps did not contribute to nutrients for plant use during the spring growing season, but perhaps will be a source to the subsequent plantings. The M-3 extracted $\mathrm{P}$ concentration in the top 6 inches of the soil also accumulated to $211 \mathrm{mg} \cdot \mathrm{kg}^{-1}$ (spring) and $381 \mathrm{mg} \cdot \mathrm{kg}^{-1}$ (fall) (Table 2). Phosphorus fertilizer was not applied to the plots in either the spring or the fall season. Therefore, it may not be that $\mathrm{P}$ levels increased between 
seasons, but that $\mathrm{P}$ became more available in the fall. Levels of $P$ are excessively high in the soils of Florida, and the build-up of P over time is a common trend increasing P solubility. The M-3 extracted K concentration, on the other hand, decreased from preplant to $35 \mathrm{mg} \cdot \mathrm{kg}^{-1}$ (spring) and $29 \mathrm{mg} \cdot \mathrm{kg}^{-1}$ (fall), signifying that $\mathrm{K}$ stratified or moved farther down from the top 6 inches of the soil depth in the sandy soil profile. Overall, $\mathrm{pH}$ did not change very much, where both spring and fall had a pH of 6.2. EC was not measured at preplant, but EC values at harvest were the same for both seasons $\left(0.12 \mathrm{mS} \cdot \mathrm{cm}^{-1}\right)($ Table 2$)$.

\section{Conclusions}

For fresh yields, a regression analysis showed that yields were maximized at 162 and $233 \mathrm{lb} /$ acre of $\mathrm{N}$ in the spring and fall seasons, respectively. Whole plant $\mathrm{N}$ accumulation, NUE, and APR declined when $\mathrm{N}$ rates increased above $150 \mathrm{lb} /$ acre. The highest NUE of $12.05 \%$ (spring) and $32.38 \%$ (fall) were recorded at the lowest rate of $150 \mathrm{lb} /$ acre. Nitrogen use efficiency significantly decreased with increasing rates of $\mathrm{N}$ fertilizer applied in both seasons. Such information could aid in improving $\mathrm{N}$ management practices to maximize efficiency and minimize losses under various climatic conditions. Therefore, further fine-tuning of the current recommended $\mathrm{N}$ fertilizer rates may be considered only after multiyear conclusive field studies with multiple $\mathrm{N}$ rates.

\section{Literature cited}

Adams, S.R., K.E. Cockshull, and C.R.J. Cave. 2001. Effect of temperature on the growth and development of tomato fruits. Ann. Bot. 88:869-877.

Anderson, P.C., F.M. Rhoads, S.M. Olson, and K.D. Hill. 1999. Carbon and nitrogen budgets in spring and fall tomato crops. HortScience 34:648-652.

Baligar, V.C., N.K. Fageria, and Z.L. He. 2001. Nutrient use efficiency in plants. Commun. Soil Sci. Plant Anal. 32:921-950.

Carpenter, S.R., N.F. Caraco, D.L. Correll, R.W. Howarth, A.N. Sharpley, and V.H. Smith. 1998. Nonpoint pollution of surface waters with phosphorus and nitrogen. Ecol. Appl. 8:559-568.

Charles, W.B. and R.E. Harris. 1972. Tomato fruit-set at high and low temperatures. Can. J. Plant Sci. 52:497-506.
Craswell, E.T. and D.C. Godwin. 1984. The efficiencies of nitrogen fertilizer applied to cereals in different climates. Adv. Plant Nutr. 1:1-55.

Everett, P.H. 1976. Effect of nitrogen and potassium on fruit yield and size of mulch-grown staked tomatoes. Proc. Florida State Hort. Soc. 89:159-162.

Fixen, P., F. Brentrup, T.W. Bruulsema, F. Garcia, R. Norton, and S. Zingore. 2015. Nutrient/fertilizer use efficiency: Measurement, current situation and trends, p. 8-38. In: Managing water and fertilizer for sustainable agricultural intensification. 11 Nov. 2019. <http:// www.iwmi.cgiar.org/Publications/ Books/PDF/managing_water_and_ fertilizer_for_sustainable_agricultural_ intensification.pdf $>$.

Florida Department of Agriculture and Consumer Services (FDACS). 2015. Water quality/quantity best management practices for Florida vegetable and agronomic crops. 10 Jan. 2020. <https:// www.fdacs.gov/content/download/ $77230 /$ file/vegAgCropBMP-loRes pdf>.

Food and Agriculture Organization of the United Nations (FAO). 2015. World fertilizer trends and outlook to 2018. 16 Feb. 2018. <http://www.fao.org/3/ai4324e.pdf>.

Greenwood, D.J. and J. Hunt. 1986. Effect of nitrogen fertilizer on the nitrate contents of field vegetables grown in Britain. J. Sci. Food Agr. 37:373-383.

Heuvelink, E. 2005. Tomatoes. CABI Publ., Cambridge, MA.

Hochmuth, G. and K. Cordasco. 2000. A summary of $\mathrm{N}, \mathrm{P}$, and $\mathrm{K}$ research with tomato in Florida. Vegetable Nutrition Management Series. Hort. Sci. Dept. Florida Coop. Ext. Serv., Inst. Food Agr. Sci., Univ. Florida, Gainesville.

Hochmuth, G. and E. Hanlon. 2014. A summary of $\mathrm{N}, \mathrm{P}$, and $\mathrm{K}$ research with tomato in Florida. Univ. Florida, Inst. Food Agr. Sci. SL355. 20 Nov. 2018. <http://edis.ifas.ufl.edu/cv236>.

Jansson, S.L. and J. Persson. 1982. Mineralization and immobilization of soil nitrogen, p. 229-248. In: F.J. Stevenson (ed.). Nitrogen in agricultural soils. Amer. Soc. Agron., Madison WI.

Kadiyala, M.D.M., R.S. Mylavarapu, Y.C. Li, G.B. Reddy, K.R. Reddy, and M.D. Reddy. 2014. Uptake efficiency of 15Nurea in flooded and aerobic rice fields under semi-arid conditions. Paddy Water Environ. 13:545-556.

Locascio, S.J., G.J. Hochmuth, F.M. Rhoads, S.M. Olson, A.G. Smajstrla, and
E.A. Hanlon. 1997. Nitrogen and potassium application scheduling effects on drip-irrigated tomato yield and leaf tissue analysis. HortScience 32:230-235.

Masclaux-Daubresse, C., F. Daniel-Vedele, J. Dechorgnat, F. Chardon, L. Gaufichon, and A. Suzuki. 2010. Nitrogen uptake, assimilation and remobilization in plants: Challenges for sustainable and productive agriculture. Ann. Bot. 105:1141 1157.

Mengel, K. and E.A. Kirkby. 2001. Nitrogen. Principles of plant nutrition. Kluwer Academic Publ., Dordrecht, The Netherlands.

Mengel, K., B. Hutsch, and Y. Kane. 2006. Nitrogen fertilizer application rates on cereal crops according to available mineral and organic soil nitrogen. Eur. J. Agron. 24:343-348.

Mylavarapu, R., G. Hochmuth, and G. Liu. 2017a. UF/IFAS standardized nutrient recommendations for vegetable crop production in Florida. Soil Water Sci., IFAS Coop. Ext. Serv., Univ. Florida CIR1152.

Mylavarapu, R.S., W. d'Angelo, N. Wilkinson, and D. Moon. 2017b. UF/ IFAS extension soil testing laboratory (ESTL) analytical procedures and training manual. Soil Water Sci., IFAS Coop. Ext. Serv., Univ. Florida Circ. 1248.

Paltineanu, I.C., C. Hera, R. Paltineanu, A. Idriceunu, G. Eliade, G. Suteu, M. Bologa, A. Canarache, T. Postolache, and I. Apostol. 1980. Irrigation water and N fertilizer application efficiencies for reduction of water and $\mathrm{N}$ losses and for water pollution control, p. 169-193. In: Proc. Soil Nitrogen as Fertilizer or Pollutant Res. Coordination Mtg., Piracicaba, Brazil, 3-7 July 1978, Intl. Atomic Energy Agency, Vienna, Austria.

Rhoads, F.M., S.M. Olson, G.J. Hochmuth, and E.A. Hanlon. 1996. Yield and petiolesap nitrate levels of tomato with $\mathrm{N}$ rates applied preplant or fertigated. Proc. Soil Crop Sci. Soc. Fla. 55:20-22.

Sato, S., M.M. Peet, and J.F. Thomas. 2000. Physiological factors limit fruit set of tomato (Lycopersicon esculentum Mill.) under chronic, mild heat stress. Plant Cell Environ. 23:719-726.

Smil, V. 1999. Nitrogen in crop production: An account of global flows. Global Biogeochem. Cycles 13:647-662.

Syers, J.K., A.E. Johnston, and D. Curtin. 2008. Efficiency of soil and fertilizer phosphorus use, reconciling changing concepts of soil phosphorus behavior with agronomic information. FAO Fert. Plant Nutr. Bul. 18. 14 Nov. 2019. <http:// www.fao.org/3/a-al595e.pdf>. 
U.S. Department of Agriculture. 2011. Florida agriculture by the numbers. 14 Nov. 2019. <https://www.nass.usda.gov/ Statistics_by_State/Florida/Publications/ Annual_Statistical_Bulletin /FL_ Agriculture_Book/2011/2011\%20FL\% $20 \mathrm{Ag} \% 20$ by $\% 20$ the $\% 20$ Numbers.pdf>.

U.S. Department of Agriculture. 2017. Web soil survey. 13 Jan. 2018. <http:// websoilsurvey.sc.egov.usda.gov>.

U.S. Department of Agriculture. 2018. Vegetables 2017 summary. 14 Nov. 2019. <https://downloads.usda.library. cornell.edu/usda-esmis/files/02870v86p/ $5425 \mathrm{kd} 81 \mathrm{z} / 9019 \mathrm{~s} 517 \mathrm{t} /$ VegeSumm-0213-2018.pdf>.

Way, P.L. 2007. Development of a functional, widely accepted and adopted BMP program in response to government regulation. Amer. J. Potato Res. 84:39-46.

Xu, G., X. Fan, and A.J. Miller. 2012. Plant nitrogen assimilation and use efficiency. Annu. Rev. Plant Biol. 63:153182.

Zemenchik, R.A. and K.A. Albrecht. 2002. Nitrogen use efficiency and apparent nitrogen recovery of Kentucky bluegrass, smooth bromegrass, and orchardgrass. Agron. J. 94:421-428.

Zotarelli, L., J.M. Scholberg, M.D. Dukes, and R. Muñoz-Carpena. 2007. Monitoring of nitrate leaching in sandy soils: Comparison of three methods. J. Environ. Qual. 36:953-962.

Zotarelli, L., J.M. Scholberg, M.D. Dukes, R. Muñoz-Carpena, and J. Icerman. 2009a. Tomato yield, biomass accumulation, root distribution and irrigation water use efficiency on a sandy soil, as affected by nitrogen rate and irrigation scheduling. Agr. Water Manage. 96:23-34.

Zotarelli, L., M.D. Dukes, J.M. Scholberg, R. Muñoz-Carpena, and J. Icerman. 2009 b. Tomato nitrogen accumulation and fertilizer use efficiency on sandy soil, as affected by nitrogen rate and irrigation scheduling. Agr. Water Manage. 96:12471258 .

Zuraiqi, S., W. Qawasmi, I. Deek, and M.J. Mohammad. 2002. Management of nitrogen fertigation of tomato with the use of ${ }^{15} \mathrm{~N}$ technology. Joint FAO/Intl. Atomic Energy Agency Div. Nuclear Techniques in Food Agr., Vienna, Austria. 